\title{
City Branding and Destination Branding in Urban Culture View
}

Amalia Herlina ${ }^{1}$

1Universitas Nurul Jadid Paiton, Probolinggo, Indonesia

\begin{tabular}{ll}
\hline ARTICLE INFO & ABSTRACT \\
\cline { 2 - 3 } $\begin{array}{l}\text { Received June 2020 } \\
\text { Accepted June 2020 } \\
\text { Published July 2020 }\end{array}$ & $\begin{array}{l}\text { This article discusses various aspects of city branding and } \\
\text { destination branding activities that are reviewed in an urban } \\
\text { culture perspective. This article is a series of opinions composed } \\
\text { of a variety of literature reviews to support the development of } \\
\text { the concepts of city branding and destination branding. This } \\
\text { Keywords: City Branding, } \\
\begin{array}{l}\text { Destination Branding, Urban } \\
\text { Culture. }\end{array}\end{array}$ \\
$\begin{array}{l}\text { the urban economy. The new picture has raised the urban } \\
\text { recovery ventures in associations with regions and private } \\
\text { associations. Urban industry was supplanted by administration } \\
\text { segments like promoting, money and correspondence in this } \\
\text { period. }\end{array}$ \\
\hline
\end{tabular}

\section{Introduction}

Urban areas plan their characters to advance and market themselves simply like items are promoted in item advertising. Districts and establishments intricately organize open territories to make their urban areas all the more engaging and welcome guests to different exercises and occasions. Urban communities accentuate their uniqueness by logos, mottos and limited time crusades to separate themselves simply like items are separated side-effect characters, brands, logos and special battles[1]. Numerous pros accept that selling urban areas are more mind boggling than promoting and selling items. Destination branding is also a substantially more unpredictable procedure than item marking since there are increasingly autonomous things included. Clashes can happen while utilizing society for urban recovery, because of the people groups' impression of culture[2].

There could be different advantages of city branding including trustworthiness, speculation attraction, the travel industry improvement, expanded political impact, fascination of worldwide accomplice ships for neighborhood research and instructive associations, or 'locale of birthplace' impact. Conversely the item marking, the character of a spot couldn't be resolved from the zero base and negative picture that exist in a city couldn't be supplanted, it could simply be pushed to opposite side, in light of the fact that urban areas have a foundation, history, culture, legacy that couldn't be rearranged[3]. That recovery procedure is mistaking for urban communities since they have numerous advantages and they are eager to advance all, so it could be difficult to put all independently focused on battles under one umbrella. In this manner the partners need to coexist with a shared opinion, position their place and battle for that reason[4]. 
Next to those outside constructive outcomes, there could be interior ones also; prompting a more grounded network, expanding the community pride and support.

\section{Research Methods}

This article discusses various aspects of city branding and destination branding activities that are reviewed in an urban culture perspective

\section{Result and Discussion}

City branding and destination branding system: Structuring and executing a destination branding system requires an intricate arrangement of activities, including a wide number of open and private partners assembled in a system that are perfect with one another [5]. The most significant point in destination branding is that the way of life ought not be made and duplicated with regards to social the travel industry; the city needs to rethink its character with regards to its nearby culture [6]. In corresponding with that approach, all partners that take job in destination branding methodology need to battle for a typical advantage and spotlight on a similar objective. In any case, most urban communities incline toward advancing legitimately their societies which have not yet been delivered [7]. Unfortunately, there is a distortion about how culture is comprehended and utilized set up marking. There are two obvious decisions while utilizing society in destination branding; the first utilizing society as a strategic or reactant component and the subsequent one utilizing social advancement as a vital objective for intercessions to focus on [1].

Surveying the way of life drove recovery is clashing because the appraisals for the most part center around assessing the financial, physical and social effects, without thinking about the social advantages. It is difficult to defeat all the negative pictures of a city just by utilizing social crusades. There would consistently be assorted varieties between the briefs of the battles and the adjustment of them to the regular day to day existence. Destination branding procedures must be modifiable and versatile to be actualized [2]. Thus, it's seen that culture and legacy are viewed as triggers to advance spots. Culture is utilized for urban recovery and particularly the worldwide occasions have significant significance in that execution. In any case, it is a urgent choice that must be made by the partners which profit by that marking. The partners that structure and execute destination branding procedures are for the most part the districts and activities [4].

Urban culture and branding: There are likewise numerous difficulties that the partners need to defeat for an effective destination branding and the hugest ones of that difficulties are recorded. Cities have numerous highlights, for example, their societies, legacy, nearby life, and neighborhood charactersp [3]. Yet, while situating the city, the destination branding procedure must be clear and the city ought not be advanced with numerous characters. Since having greater character makes situating entangled and excess.

Culture can be an impetus in destination branding methodology yet ought not be seen as an enchantment wand that will take care of all the negative issues of the city. It can give a positive picture to the city, draw in more guests and make more business 
open doors that can give more salary. Be that as it may, all issues of city, for example, joblessness, vagrancy, and foundation ought not be relied upon to be explained just by culture itself. Cultural legacy is an idea utilized in the production of goal and it is the central point for sightseers to pick that goal. If the social legacy is utilized seriously, it could lose its curiosity and be declined, along these lines care must be taken to utilize and secure [1].

Culture is the lifestyle that incorporates workmanship, conviction, good and propensities; it couldn't be a choice of anybody. These qualities can't be required to be created and continued with quick deci-sion makings. This is the reason partners ought not consider culture to be an item marking; they ought to decide the marking methodology as per how they use culture [6]. Something else, on the off chance that they endeavor to make a nonexistent culture, a counterfeit, unreasonable urban picture will develop. In ongoing years, the travel industry has gotten the fundamental goal of the destination branding systems.

The significant reason for existing is drawing in more sightseers and more business systems [2]. Other than those objective gatherings, the city has its own inhabitants that must be happy with the offices, so at first the city brand-ing needs to fulfill its own occupants. All partners need to concede to the issues about advancing the city. They could anticipate different advantages, yet they need to concentrate on a similar issue. Something else, a wide range of executions in different regions of the destination branding technique happen and that could cause strife which brings about situating disappointment [1].

Destination branding methodologies must be in corresponding with urban strategies. As it is found in the excellent cases, the principle on-screen characters in that procedures are the nearby governments in this manner it is preposterous to expect to isolate marking methodologies from the neighborhood approaches. Open and private approaches must be on a similar line [3].

Destination branding has likenesses to item marking, yet it is substantially more mind boggling because of presences of it before the marking usage [7]. An item is structured, created, situated, elevated, and offered to a particular objective. In any case, a spot doesn't have zero point like an item has, it couldn't be accepted that a city developed with marking systems [5]. Destination branding is a multi-faceted application that has numerous partners and many objective gatherings, and it is considerably more near corporate marking with those highlights.

The rundown above is shaped by breaking down the destination branding cases in writing, and it very well may be considered as a rundown of proposals for the partners. The partners ought to research the urban communities having a fruitful marking picture and can follow their way. In any case, a model that is valuable for a city doesn't really mean it will fit to another. Each city has its own way of life, foundation, occupants, guests, issues, and spot marking procedure [3]. It's anything but a dress that is bought from a store and expected to fit everybody, since it resembles a dress that is custom-made for people. Accordingly, every city has its own issues, abilities, offices, and the partners need to decide the destination branding technique in corresponding with those highlights and use culture in that methodology. 
The essential objective of relationship promoting is to assemble and keep up a submitted customer base who is productive for the organization [6]. Faithful customers give a strong base of income stream for the organization just as they may speak to development potential, since they purchase more items and administrations from the organization after some time. With regards to maintenance promoting, organization needs to distinguish customers who are gainful to serve and discover approaches to stay with them [2]. Improving customer degrees of consistency while diminishing the deserting rates is a significant goal for the Customer Relationship Management (CRM) methodologies; because drawn out organization achievement relies upon the organization's capacity to develop from loyalty.

Organizations actualize maintenance promoting rehearses in endeavor to build customers' promise to the organization. In this way, promoting's crucial to guarantee and facilitate the exercises that will cultivate customer maintenance and loyalty. Organizations must focus on high satisfaction; since high satisfaction makes a passionate bond with the firm and thus, this will prompt customer maintenance. An organization can keep up customer maintenance and unwaveringness through consumer loyalty, prevalent assistance, dependability programs, deserting examination, protest taking care of, mass customization, customer focusing on and database advertising [7]. To keep up consumer loyalty, organizations need to find out about customers' desires and needs. Listening the voice of customers is basic to find out about the customers' desires and needs.

\section{Conclusion}

The deindustrialization stage framework spotted in the urban communities has prompted changes in city economies. The new conditions have changed the urban economy, yet in addition pictures of the urban areas. The new picture has raised the urban recovery ventures in association with regions and private associations. Urban industry was supplanted by administration segments like promoting, money and correspondence in this period. The nearby governments and the private divisions have taken care of culture as a capacity to recover the pictures of urban areas. Destination branding dependent on culture is supported for the most part by the travel industry. The job of culture in the city advancing techniques is also assessed through the investigation of cases.

\section{References}

[1] Customer Loyalty of Environmentally Friendly Electronics Products," Kasetsart J. Soc. Sci., vol. 38, no. 1, pp. 24-30, 2017, doi: 10.1016/j.kjss.2016.08.012.

[2] W. Kim, H. Kim, and J. Hwang, "Sustainable Growth for the Self-Employed in the Retail Industry Based on Customer Equity, Customer Satisfaction, and Loyalty," J. Retail. Consum. Serv., vol. 53, no. October 2019, p. 101963, 2020, doi: 10.1016/j.jretconser.2019.101963.

[3] Pinasti, Rohry Dinda. TA: Penciptaan Buku Komik sebagai Upaya Pengenalan Permainan Tradisional kepada Remaja. Diss. Institut Bisnis dan Informatika Stikom Surabaya, 2015. 
[4] J. G. Langhof and S. Güldenberg, "Pirates, Ghosts and Customer Loyalty Reviewing the Dark Ride Experience," Tour. Manag. Perspect., vol. 31, no. June, pp. 398-420, 2019, doi: 10.1016/j.tmp.2019.06.004.

[5] Marzuqi, Ahmad. TA: Penciptaan Motif Batik sebagai Ikon Kabupaten Lumajang. Diss. Institut Bisnis dan Informatika Stikom Surabaya, 2015.

[6] J. S. Wolter, D. Bock, J. S. Smith, and J. J. Cronin, “Creating Ultimate Customer Loyalty Through Loyalty Conviction and Customer-Company Identi fi cation," J. Retail., 2017, doi: 10.1016/j.jretai.2017.08.004.

[7] M. Srivastava and A. K. Rai, "Mechanics of Engendering Customer Loyalty: A Conceptual Framework," IIMB Manag. Rev., pp. 1-12, 2018, doi: 10.1016/j.iimb.2018.05.002. also assessed through the investigation of cases. 